\title{
COMPARISON OF LEGISLATION AFFECTING FOREIGN EXPLOITATION OF OIL AND GAS RESOURCES IN OIL PRODUCING COUNTRIES
}

\author{
MARTIN M. OLISA*
}

\begin{abstract}
Foreign investment in Canada, not only in the oil and gas industry but in all Canadian industry, is a topical issue. This article summarizes and compares the typical legislative and contractual provisions that are used by the govern. ments of other oil producing countries with respect to the terms and conditions upon which the oil and gas industry can participate in the exploration and production of their oil and gas resources. The article discusses the requirements that are imposed on foreign applicants for oil and gas rights, the methods used to maximize the returns to the host country, the stipulations with respect to government participation in and supervision of the foreign enterprise, and leaves it to the reader to decide for himself whether any such provisions or similar provisions should be applied to foreign participation in the Canadian oil and gas industry.
\end{abstract}

\section{A. INTRODUCTION}

Many countries whose oil and gas resources are being developed mainly or entirely by foreign capital have formulated policies bearing on oil and gas specifically or within the context of comprehensive energy policies. In the absence of deliberate oil or energy policies, some of the countries have broad and flexible guidelines which more or less serve similar ends as deliberate oil policies. In general, the policies and guidelines are designed, on the one hand, to encourage foreign capital for oil and gas development, and on the other, to ensure that oil and gas development by foreign capital is carried out with proper regard to what each particular country considers to be its national interests. Such matters as national sovereignty over oil and gas resources, ownership, control or management of foreign owned oil companies, oil and gas revenue and participation by nationals or by government in the ownership and control of such companies, receive attention in the policies and guidelines.

The policies, deliberate or otherwise, later become the main basis for legislation governing oil and gas operations in the country. Similarly, amendments to oil and gas legislation derive quite frequently from specific policies on particular aspects of oil and gas operations.

Contents of national oil policies and statutory provisions that derive from them vary from one oil producing country to another and depend to a large extent on national factors such as each country's political, economic and social aspirations. Because of diverse national interests, developing countries that produce mainly for export lay emphasis on measures designed to increase oil and gas revenue, whereas highly industrialized countries that have not attained self-sufficiency in oil and gas from domestic production give priority to measures for adequate and steady importation of cheap oil and gas to supplement domestic production. Another example is that economic nationalism, directed against foreign owned oil companies, finds fertile ground in many

- B.Sc. (London), LL.B. (London), LL.M. (Alta.). Barrister, Middle Temple; Member of the Law Society of Alberta; Solicitor, Aquitaine Company of Canada Ltd., Calgary, Alberta. 
countries where the oil industry or a large percentage of it is under the ownership and control of foreign nationals or parent corporations. In many oil producing countries, such national factors have from time to time found expression in statutory provisions. Therefore, it is important that one should view the provisions quoted in this paper against the background, firstly, of national factors that influence the oil and gas legislation of each respective country, and secondly, of the international dimensions of the oil industry.

A word about the statutory provisions quoted in this paper; they are chosen from Basic Oil Laws and Concession Contracts (Original Text) ${ }^{1}$. A vast majority of the provisions represents, as at the end of 1970, the state of oil and gas legislation of many oil producing countries in so far as such legislation affects foreign development of oil and gas resources.

This paper considers the provisions in relation to the objectives they are designed to achieve. It is also a comparative study.

\section{B. PROVISIONS DESIGNED TO FURTHER POLITICAL OBJECTIVES}

\section{Sovereignty Over Oil and Gas in Place}

The first few provisions of oil and gas legislation of most oil producing countries proclaim, in effect, national sovereignty over oil and gas resources underlying their respective geographical boundaries. Each oil producing country with a coastline has also declared its jurisdiction and control over oil and gas underlying the sea bed and subsoil of its territorial waters and beyond that to the outer limits of its continental shelf. The rights of other nations or persons to use international waters for fishing, navigation and other purposes recognized in international law are not affected by such a declaration of sovereignty.

In a vast majority of the countries, ownership of oil and gas in place belongs to the State and title vests in the national government. ${ }^{2}$ State ownership does not preclude private exploitation in most of the countries. In the constitutions or in oil and gas legislation of most oil producing countries with a federal form of government, ownership of oil and gas in place is allocated, as to specific areas or territory, to the Federal government and the provinces or states. ${ }^{3}$ However, interprovincial or interstate and international pipelines and the exporting or importing of oil and gas are under the jurisdiction of national governments. ${ }^{4}$ Except in Canada, the United States, Colombia and possibly Denmark, individuals have no title to oil and gas in place. Issues involving national sovereignty over oil and gas resources are often in evidence in the relationships between various international oil companies and national governments of oil producing countries particularly in North Africa, the Middle East and South America. The full scope of national sovereignty over natural resources cannot be considered in this paper. In this regard, the Appendix to this paper (The Resolution of the United Nations General Assembly concerning Permanent Sovereignty over Natural Resources) contains a lot of basic information, some of which

\footnotetext{
1 (Burrows 1965).

2 E.g., Algeria, Argentina, Brazil, Indonesia, Nigeria and Venezuela.

3 Australia, Canada, Germany, United States.

- E.g., British North America Act, 30 \& 31 Vic., c. 3, ss. $91,92$.
} 
underlies national oil policies as well as the statutory provisions quoted in this paper.

\section{EXAMPLES:}

\section{ALGERIA}

Article 1. . . prospecting and exploration operations for liquid and gaseous hydrocarbons may not be undertaken, even by the owner of the surface, except pursuant to:

a prospecting authorization; or an exclusive exploration permit designated as $\mathrm{H}$. permit. $^{5}$

LIBYA

Article 1(i). All petroleum in Libya in its natural state in strata is the property of the Libyan State.

No person shall explore or prospect for, mine or produce petroleum in any part of Libya, unless authorized by a permit or concession issued under this Law. ${ }^{6}$

\section{NIGERIA}

Section 3(i). The entire property in and control of all minerals and mineral oils, in, under or upon any lands in Nigeria, ... . is and shall be vested in the State.?

\section{VENEZUELA}

Article 1. Everything relative to exploration of (in) the national territory in search of petroleum, asphalt, natural gas and other hydrocarbons; to the exploitation of deposits thereof whatever may be their origin or location; to the manufacture or refining of such substances exploited, to the transportation by special means and the storage thereon and to the handling facilities therefor, is declared to be of public utility and shall be governed by the present law. ${ }^{8}$

\section{BELGIUM}

The Kingdom of Belgium exercises its sovereign rights over the continental shelf as it is defined in Article Two of the present law for the purposes of exploration of same and the exploitation of its natural resources. ${ }^{9}$

\section{BRITAIN}

1. (1) Any rights exercisable by the United Kingdom outside territorial waters with respect to the sea bed and subsoil and their natural resources, except so far as they are exercisable in relation to coal, are hereby vested in Her Majesty. ${ }^{10}$

\section{Eligibility of Foreign Applicants}

In general, the oil and gas legislation of most oil producing countries does not impose restrictions based on nationality; citizens and foreigners are eligible for grants of permits, licences, leases or concessions, as the case may be. Some provisions, however, are especially applicable to foreigners or place citizens in a more favourable position in acquiring oil and gas exploitation rights. For example, ${ }^{11}$

Egyptians shall have priority over Non-Egyptians in obtaining prospecting licences in case it is not possible to determine the priority as provided in Article 7; likewise, Egyptians shall also have the priority in obtaining prospecting licences and Mining Leases through public auctions in case of parity of offer.

Other provisions of special application to foreign applicants contain

3 Statute No. 58-111, November 22, 1958, Art. 1. Art. 18 contains a similar provision relating to exploitation concessions.

- The Petroleum Law 1955, Law 25.

7 An Ordinance to Amend and Consolidate the Law Relating to Mines and Minerals, Laws of the Federation of Nigeria, (1958 Ed.) Cap. 121 as amended by Legal Notice No. 112 of 1964, Federation Nigeria Gazette (1964).

- Law of Hydrocarbons, March 13, 1943. This Law was repealed and reenacted by a law dated August 7, 1967.

9 Continental Shelf Law, June 13, 1969.

30 Continental Shelf Act, 12 \& 13 Eliz. 2, c.29, в. 1.

"Law No. 66 of 1953 on Mines and Quarries, Art. 40. 
requirements relating to incorporations under the laws of the host country (Denmark, Canada, United States, Britain, Spanish Sahara, Colombia, France), the number of incorporators that must be citizens or have residence qualifications (Denmark, Sweden), election of domicile (Egypt, Colombia, France), registration and appointment of resident legal representative (Algeria, Canada, Nigeria, Libya) and the number of citizens in the management or supervisory board of directors (Portugal, Britain, Denmark, Egypt, France). Although the legislation of most of the countries places no limitation as to the ownership of stock or shares by foreigners, yet under the legislation of some countries (Britain, United States, Sweden) not more than a specified percentage of the capital of an oil company may be held by foreigners; information regarding stock owners is usually supplied in support of an application for exploitation rights.

In a few oil producing countries (Argentina, Mexico, Venezuela) only service contracts are awarded to foreign oil developers rather than granting them exploitation rights. In the legislation of some countries (Spain,12 Venezuela, Portugal) it is provided that oil and gas rights may not be granted to a foreign government or its intermediary or to a company which is controlled up to a specified percentage by a foreign government.

The Mineral Leasing Act of $1920^{13}$ of the United States contains a provision that permits or leases may not be granted to companies or persons whose national laws do not allow United States citizens to acquire similar privileges. The oil and gas legislation of Denmark, Britain, Italy, Iran and Germany contains similar provisions that embody the principle of reciprocity.

Under the Canada Oil and Gas Land Regulations, ${ }^{14}$ a lease will not be issued to any corporation incorporated outside of Canada or to any corporation unless either:

(a) at least 50 per cent of the issued shares of the corporation are beneficially owned by persons who are Canadian citizens,

(b) the shares of the corporation are listed on a recognized Canadian stock exchange and Canadians have an opportunity of participating in the financing and ownership of the corporation, or

(c) the shares of the corporation are wholly-owned by a corporation that meets the above requirements.

As a prerequisite to the granting of concessions or awarding service contracts by the national governments of some major producers of North Africa and South America, there is one class of requirements which is in the nature of a commitment on the part of a foreign concessionaire. The commitment may directly involve a foreign oil company in industrial or social projects of the host country outside the normal sphere of activity of the oil company, for example, building and maintaining hospitals and building schools. The projects or services to be undertaken or provided by the foreign oil company are not specifically written into oil and gas legislation but the legislation empowers the proper governmental authority to negotiate the terms and conditions of each concession with foreign oil companies. Some of the guidelines laid down by legislation for determining the eligibility

\footnotetext{
12 Hydrocarbon Act, December, 1958, The Petroleum Legislation, Spanish Sahara.

is 41 Stat. 437, 30 U.S.C., 8. 181 et seq.

14 S. 55.
} 
of an applicant are couched in expressions like "in the furtherance of public interest"15 or "special advantages for the nation": 16

The Federal Executive is authorized to stipulate special advantages for the Nation with any party making application for any of the concessions to which this law refers.

The statutory requirements for eligibility for the issuance of exploitation rights, together with those that apply to citizens and foreigners alike, serve the purpose of furnishing a national government with information pertaining to the structure, organization, ownership and control of foreign owned oil companies which carry on business in the country. More importantly, they aim at placing foreign owned oil companies under the jurisdiction of the laws of the host country. The legislation of some of the countries (Portugal) expressly demands a waiver by a foreign company of any special treatment and a declaration of submission to the laws of the host country. ${ }^{17}$ Thus the provisions are designed to give the government of the host country some control over the activities of foreign oil companies, at least "from the outside". It will be recalled that the legislation of some of the countries (Portugal) provides that a specified number of citizens must be members of the Board of Directors of the company. The objective of such requirements is to provide the country with some control over the management of the company "from the inside"; this measure is an attempt at shifting the business power of the company from abroad to the nation so that the decisions of the company may be nationally oriented. Other acts of encroachment by national governments into what was once the prerogative of private enterprise-internal management or control of a private company under free enterprise system-will be discussed later.

\section{EXAMPLES:}

ITALY

The Exploration permit shall be granted to applicants, Italian nationals or corporations with Company Office in Italy, who possess adequate technical and financial capacity. ${ }^{18}$

\section{FRANCE}

Subject to the exception which may be granted by decree, any commercial company which is the concessionaire or lessee of the . . mine must be established under French law and satisfy the following conditions:

If the company is a corporation, the chairman of the board of directors, the general manager, the auditors and at least two-thirds of the members of the board of directors shall be French. ${ }^{19}$

BRITAIN

(2) The application for

(i) a prospecting licence or

(ii) a mining licence

shall state:

(b) in the case of an application by a company, the principal place of business

1s Decree Law For Oil Concessions in the Offshore of Metropolitan Portugal, Art. 5(d).

16 Venezuela: Law on Hydrocarbons, March 13, 1943, Art. 5 Special Paragraph. This Law has been repealed and reenacted by a law dated August 7,1967; no new concessions are to be issued to other than the government oil company.

17 Supra, n. 15.

10 Law Decree No. 715, May, 1925, extended and modified by Law No. 684, May 21, 1956, Art. 2.

10 Terms and Conditions, October 6, 1955 (Terms and Conditions For The Liquid or Gaseous Hydrocarbon Mine Concession of ...). 
of the company, the names and nationality of the directors thereof, and the names and holdings of the principal shareholders.

(3) An application by an alien or a company incorporated outside Great Britain or Northern Ireland must give, in addition to matters specified in paragraph (2) of this Regulation, full particulars of any company intended to be incorporated in Great Britain or Northern Ireland for the purpose of receiving the grant of and exploiting any Licence which may be granted in pursuance of the application..$^{20}$

\section{UNITED STATES}

. . Citizens of another country, the laws, customs, or regulations of which deny similar or like privileges to citizens or corporations of this country shall not by stock ownership, stock holding or stock control, own any interest in any lease acquired under the provisions of this Act. ${ }^{21}$

\section{SWEDEN}

The Concession may be supplemented by such stipulations as are called upon with a view to the public interest, for example as regards the management of the company concerned,...22

\section{COLOMBIA}

Companies whose principal place of business is located in a foreign country and which desire to establish themselves in Colombia and to enter into contracts relating to oil with the Nation or with individuals must constitute and domicile a firm or branch, even though they are not general partnerships, at the capital of the Notarial Circuit of Bogota, pursuant to the provisions of Article 470 and related provisions of the Commercial Code. Such firm shall be considered as Colombian for all national and international purposes connected with said contracts and with the properties, rights and actions thereunder. ${ }^{23}$

\section{LIBYA}

... and in determining the eligibility of any applicant, the [Council of Ministers] shall have regard to the following:

(a) the furtherance of public interest; 24

\section{PORTUGAL}

On public bids, further to the conditions that can be established in each case, it will be also always required from each one of the bidders:

(d) if foreign, a declaration of the renouncement of any special treatment and submission to what is prescribed in Portuguese legislation, everything connected to the activities relating the concessions to be obtained. ${ }^{25}$

\section{PROVISIONS DESIGNED TO GENERATE NATIONAL REVENUE AND LOCAL CAPITAL}

Government revenue from oil originated with the payment of a fixed royalty per barrel (or ton) of production. Within recent years, new measures for raising government oil revenue and local capital have come into prominence. The most noteworthy of these measures are as follows:

(a) income tax;

(b) profit-sharing arrangement (the 50:50 formula);

(c) mandatory area relinquishment and the bidding system;

\footnotetext{
30 The Petroleum (Production) Regulations, 1935, made by the Board of Trade under section 6(1) of the Petroleum (Production) Act, (Imp.) 24 \& 25 Geo. 5, c. 36.

21 The Mineral Leasing Act of 1920; 41 Stat. 437, 30 U.S.C., 8. 1 (as amended). Information required includes full disclosure of stock ownership of a foreign company applicant, showing the number of shares owned by foreigners.

22 Continental Shelf Law, June 3, 1966.

23 Decree No. 1956: The Petroleum Code Art. 10, in part. (Emphasis added).

24 The Petroleum Law, Art. 5. Since early 1970 responsibility for certain concession affairs is shared between the Council for Ministers and the Ministry of Petroleum.

25 Supra, n. 15
} 
(d) participation by host governments and foreign oil companies in joint venture in the production (and later, other stages) operations;

(e) preferential right of government or nationals to buy a fixed percentage of the capital stock of a foreign owned oil company; and

(f) commitment by foreign owned companies to reinvest a portion of their profits and to establish secondary industries such as refineries and fertilizer plants.

Some provisions of legislation and concession contracts bearing on the new measures of generating government revenue and local capital apply to foreign owned oil companies in some special ways. However, before examining the provisions it is helpful to bear in mind certain fundamental facts:

1. The controlling petroleum or hydrocarbon legislation of many major producing countries requires that concession contracts between government and foreign oil companies must receive legislative authorization. Such concession contracts are in effect special laws. Some concessions granted by Portugal (for operations in off shore areas of Angola), Egypt, Algeria, Libya and Iran contain provisions that depart from the controlling legislation. ${ }^{26}$ Therefore, in order to ascertain the present law on any matter, one has to refer to the latest concession contract and the controlling legislation, which is not followed implicitly.

2. Provisons designed to generate government oil revenue or to increase it are, in theory, generally applicable to foreign owned and private indigenous oil companies. In most oil producing countries of the Middle East, Africa and South America, however, there are hardly any private indigenous oil companies. Thus, international oil companies appear to be the target of the provisions relating to government revenue and local capital in these countries.

3. Taxation laws and policies of major oil consuming countriesthe home countries of major international oil companies-have a powerful effect on the form and amounts of taxation, direct and indirect, which the companies may be prepared to pay to governments of oil exporting countries. Because of the integrated nature and worldwide dimension of their operations, international oil companies tend to reckon their profit position from the standpoint of their total operation. On the other hand, every government of oil exporting countries tries to exact for itself more and more oil revenue.

\section{Taxes}

In general, once a foreign owned oil company becomes a corporate citizen, it also becomes subject to the same tax laws as any private indigenous oil company. Similarly, the rate for corporation tax is generally the same for oil companies as for other industrial enterprises. However, profit-sharing and joint venture arrangements, introduced by some governments, are apparently aimed at foreign oil companies and appear to obligate the companies to pay certain taxes which refer specifically to petroleum operations. These arrangements will be discussed later. ${ }^{27}$ For the moment, it is to be noted that the income taxes paid by foreign owned companies are not specific taxes for oil opera-

\footnotetext{
${ }^{28}$ E.g., the Cabinda Gulf Oil Concession granted by Portugal.

${ }^{27}$ See $n .31$ and accompanying text.
} 
tions but are those that apply generally in the country. As a relief for foreign tax, general income tax paid abroad by international oil companies based in the United States is allowed as a credit against United States income tax liability on the same foreign income. Britain, France and some other European countries give tax reliefs to their oil companies having international operations. Taxes payable by the companies in their home countries are not deductible in computing taxable profits in the host countries.

Following a recommendation by OPEC,28 now adopted by most Middle East and North African oil exporters, taxation rates are now based on posted price schedules whereby posted prices increase yearly according to a prescribed formula (Persian Gulf States, as from February 15,1971 ), whether or not such prices are actually realized in oil transactions. In computing profits, certain items of expenditure are accepted as allowable costs, others are "expensed" or "capitalized" and amortized over a long period, depending on the terms of each concession contract and the financial arrangement agreed upon between the government and company concerned.

\section{EXAMPLE:}

\section{LIBYA}

The concession holder shall pay such income tax and other taxes and imposts as are payable under the Laws of Libya but shall not be subject to any form of taxation whether Government, Provincial or Municipal or other exaction of such a nature as to render him liable to taxation or other dues not payable by persons in general operating in Libya other than fees, royalties and surface rent made payable under their law. ${ }^{29}$

\section{Profit-Sharing}

This financial arrangement is such that a tax is imposed at the rate of 50 per cent on any sum by which the net annual income of any oil company exceeds the government's total revenue derived from the company's oil operations. This arrangement involves an adjustment of payments due to the government, whether as income tax, royalty, duties or other taxes, so that the government's share of the net profits of the oil producing operations is at least equal to the net earnings of the foreign owned company.

This 50:50 formula was put into practice for the first time by Venezuela in 1943. In 1948 the law was amended to provide for a 50 per cent direct income tax so as to equalize company profits and government revenue from a company's oil operations. In 1950, the first income tax of Saudi Arabia provided for a 20 per cent levy on oil companies' net profits. Countries of the Middle East and Africa as well as Indonesia followed suit. Several financial patterns, each varying from the other, evolved from the 50:50 formula. For example, 75:25 formula in favour of the government with the foreign owned company putting up the risk capital for exploration. There were, however, heavy exploration write-offs. Another pattern consists of a payment of 50 per cent of the posted price in taxes and at the same time giving the government a 57 per cent share in the proceeds of its downstream operations. ${ }^{30}$ All sorts of profit sharing patterns have been agreed to by

\footnotetext{
28 Organization of Petroleum Exporting Countries.

29 The Petroleum Law, 1955, Art. 14. However, see, n. 24.

30 Lutfi, OPEC Oil 10 (1968).
} 
governments and foreign oil companies. In February, 1971, Persian Gulf States and some major internationals agreed to a 55:45 formula in favour of the oil States. Venezuela, by legislation, unilaterally raised its tax rate to 60 per cent in December, 1970, and is asking for more.

\section{EXAMPLE:}

\section{LIBYA}

If in respect of any complete year from and after the effective date, [defined] the total amount of the fees, rents and royalties payable under this Law and income tax other than direct taxes for which a concession holder is liable in respect of his operations and income therefrom under all petroleum concessions held by him in Libya falls short of $50 \%$ of his profits as hereinafter defined for that complete year the concession holder shall pay to [the Ministry of Petroleum Affairs] such sum by way of surtax as will make the total of his payments equal to $50 \%$ of the profits aforesaid:

If in respect of any complete year from and after the effective date the total amounts of the fees, rents and royalties payable under this Law and income tax and other direct taxes for which the concession holder is liable . . exceeds $50 \%$ of the said profits of the concession holder during that complete year he shall be entitled to carry forward such excess and, so far as may be, deduct it from or set it off against the amount of income tax and surtax, if any, payable in respect of subsequent years. ${ }^{31}$

\section{Oil Revenue Under Joint Venture}

In the 50:50 arrangements the government obtains revenue from oil companies in its capacity as a sovereign with the authority to levy taxes. In joint venture arrangements the government acts in a sovereign capacity and also as a partner in the venture. In most cases, the joint venture as a whole pays income tax based on a 50:50 formula. The government, as a partner in the venture, again takes 50 per cent of the remainder with the result that the net profits are shared 75:25 in favour of the government. Thus the 50:50 formula is applied twice. ${ }^{32}$

\section{Secondary Industries}

Foreign oil companies operating in oil exporting countries are obligated to establish in the host country refineries and other secondary industries when economically feasible. Provisions to this effect are contained in the controlling oil and gas legislation or in concession contracts and are designed to achieve certain national objectives. The objectives include the following: to provide another source of revenue for the host government; to provide an additional growth point for local capital and industrial development of the country; to provide an additional source of employment and technical training for the citizens; and as an import saving to ease the balance of payments. Ironically enough, for precisely the same objectives and perhaps other economic reasons, oil importing countries require international oil companies to build refineries and other secondary industries as a condition for entry into their markets. From time to time international oil companies are caught in a squeeze of this nature as a result of the competing interests of the importing and exporting countries. Some concessionaires in Iran, Kuwait and Saudi Arabia are under an obligation to build fertilizer plants. One of the "Preference Terms" published for the guidance of

31 Supra, n. 29. Arts. 1(a) and 1(b). Only those royalty payments at a rate of more than $121 / 2 \%$ are treated as a credit against such future tax liabilities.

32 See generally Schurr and Homan, Middle Eastern Oil and the Western World: Prospects and Problems 111. 142 (1971). 
applicants prior to the last series of concessions awarded in Libya early in 1966, was: ${ }^{33}$

The Company undertakes to construct refineries and to establish petrochemical plants within the Kingdom of Libya, in accordance with conditions to be agreed with the Libyan government.

Under the Nigerian Oil Mining Lease, the authorities are given the power to call upon the lessee to construct and operate a refinery in Nigeria.

In some concession contracts, a commitment to construct a refinery or build petrochemical plants is on a basis of equity joint venture between the foreign oil company and the host government. ${ }^{34}$

\section{Pricing and Production}

The right to set prices for oil and gas has been one of the most contentious issues between the oil industry and governments of oil producing countries. The industry insists that government control of prices strikes at the root of free enterprise, whereas governments reply that it is in the public interest to regulate the prices of oil and gas or either of them. It is beyond the scope of this paper to deal with all particular issues in dispute; the commonest issues are concerned with production and pricing.

Pricing and quantities of production are economic weapons at the hands of oil companies. They affect the profitability of their operations. On the other hand, reduction in price bears directly on the governments revenue per barrel. To some governments (Middle East, North Africa), oil is the major source of revenue and the industry is the largest tax payer. Hence in the Middle East and North Africa, governments of oil producing countries argue that economic forces, left to themselves, work to their disadvantage. They insist on having a say as to the amounts of posted prices and quantities and rates of production. This trend is not confined to the Middle East. The price of gas is regulated in Canada, France, the United States and many other countries of the Western Hemisphere. For example, prorationing schemes, regulation of import and export of oil and gas, statutory power of government agencies to regulate prices of oil and gas, and tax and other incentives in Canada and the United States tend to operate as national price support programmes. One justification for such measures is the protection of a domestic source of fuel.

In the exercise of their sovereign rights over oil and gas underlying their territories, national governments have stepped into the field of pricing which formerly was a matter of internal management for oil companies. As regards oil exporting countries whose oil and gas resources are wholly or substantially developed by foreign capital, one may argue that legislation to regulate or control the price of oil or gas is justifiable in the national interest of the producing country, even though such regulatory control is aimed at foreign owned oil companies as the first and primary target.

\footnotetext{
33 Petroleum Legislation, Africa, Libya, App. 1, at 2 (June, 1966). Libya is now a Republic with the Revolutionary Command Council as the government.

34 Abu Dhabi - Mitsubishi Group Concession signed May 14, 1968.
} 
EXAMPLES:

BRITAIN

20-(1) The Licensee shall ensure that all petroleum won and saved from the licensed area other than petroleum used therein for the purpose of carrying on drilling and production operations of pumping to field storage and refineries shall be delivered on shore in the United Kingdom unless the Minister gives notice of his consent in writing to delivery elsewhere, and in such case the Licensee shall ensure compliance with any conditions subject to which that consent is given.

(2) Any conditions imposed by the Minister on a consent under the foregoing paragraph may, without prejudice to the generality of the Minister's right to impose conditions of any nature, include provisions:

(a) as to the place of delivery;

(b) as to the price to be obtained for the petroleum to which such consent relates;

(c) as to the time within which and the manner in which payment of the price is to be made; and

(d) requiring payment to be made to a person resident in the United Kingdom..$^{35}$

\section{NETHERLANDS}

1. The licensee is prohibited to sell the natural gas produced under the license or to take it out of the undertaking in another way, if the selling price . . . has not been approved by the Minister.

2. The approval referred to in the first subsection is only refused after the licensee has been heard. The licensee is informed by a letter stating the reasons of a decision to refuse the approval. ${ }^{36}$

CANADA

Upon an application for a license [for the exportation of power or gas and for the importation of gas] the Board shall have regard to all considerations that appear to it to be relevant and, without limiting the generality of the foregoing, the Board shall satisfy itself that

(b) the price to be charged by an applicant for gas or power exported by him is just and reasonable in relation to the public interest. ${ }^{37}$

6. Other Measures

Briefly, mandatory area relinquishment or acreage reduction is a common feature of oil and gas legislation of most oil producing countries. By selling the areas relinquished by competitive bidding, governments net substantial revenue. Incidentally, one wonders whether or not acreage reduction, especially the checker-board pattern, serves the same oil revenue objectives as the joint venture arrangement discussed above. It does not appear, however, that this legislative measure is necessarily directed against foreign owned oil companies even though in practice they alone operate in any particular country.

From the point of view of oil revenue and local capital, the statutory requirement that a foreign owned oil company shall offer a specified percentage of its stocks to the government or to citizens of the host country produces results similar to joint venture arrangements. Each requirement provides an additional source of revenue for the government.

\section{PROVISIONS RELATING TO PARTICIPATION BY GOVERNMENT AND NATIONALS}

It has been pointed out that the legislation of some oil producing countries provides that a proportion of the members of the board of

ss Schedule 2, The Petroleum (Production) (Continental Shelf and Territorial Sea) Regulations 1964, Statutory Instruments, 1964 No. 708.

36 Decree of January 27, 1967, concerning implementation of Article 12 of the Continental Act, s. 24.

37 National Energy Board Act, S.C. 1959, c. 46, s. 83 (Subsection (a) is omitted). This provision applies to oil as from May $7,1970-S O R / 70-206$. 
directors of a foreign owned oil company must be citizens of the host countries (Denmark, Egypt, France, Britain). It has also been suggested that this requirement is an attempt by a national government to have some degree of control or influence over the company "from the inside". The measure of control may or may not achieve effective control but the crux of the matter is that a national government always reacts if its economic power is controlled from abroad. One result of such reaction is joint venture enterprises, which have become the rule rather than the exception in oil producing countries of Middle Asia and North Africa. Some European countries also demand joint venture arrangements (Netherlands, Sweden).

\section{Control Under Joint Venture}

The structure and contents of various joint ventures vary considerably. Without going into details, the structure is along a general basic pattern. ${ }^{38}$ As regards parties in the venture, on the national side you have private, mixed, or government-controlled enterprises ${ }^{39}$ and on the foreign side, one or more foreign enterprises. The foreign enterprise supplies the risk capital for, and carries out, exploration. Exploration expenses in whole or in part are recoverable from production, if obtained. If commercial production is obtained an equity joint venture company is established as an operating company. Participation may be on 50:50 basis or one "partner" may be in a minority position, in which case, a management contract is entered into. The foreign "partner" supplies most of the technical and managerial skill and as a result has a degree of effective control superior to its voting strength, especially if it has minority equity participation. If the national side has minority equity participation, it may be given a right of veto over certain major decisions.

Participation by governments in the oil industry is not new. There is British government participation in British Petroleum (formerly Anglo Persian and Anglo Iranian), French government participation in Entreprise de Recherches et d'Activités Petrolières (Erap), Italian government participation in Ent Nazionali Idrocarburi (ENI) and Dutch government participation in Royal Dutch/Shell. However, in the type of participation just mentioned, as in Canadian government participation in Panarctic Oils Ltd., the government contributes its share of risk capital either upon the formation of the company or actually buys its way into an existing company. Except Panarctic, all the companies mentioned are international in operation and their home countries are importers of oil in vast quantities.

Under joint venture arrangements the functions, powers and privileges of the foreign "partner" are more limited than those of a concessionaire or lessee. Nationals or the host government participate in the ownership, control and decision-making processes of the joint venture company. Nationals also participate at all levels in day to day operations, acquiring various skills in the process. The functions, powers and privileges of the foreign "partner" are so defined as to promote the national interests of the host country. Since both partners

\footnotetext{
3s See Mughraby, Permanent Sovereignty Over Oil Resources, A Study of Middle East Concessions and Legal Change at 55-70.

39 Such as National Iranian Oil Company, Indonesian National Oil Company, Kuwait National Petroleum Company and Libyan National Oil Corporation.
} 
stand to lose if the venture fails, joint venture arrangements usually provide for additional incentives and privileges to encourage foreign investors.

\section{EXAMPLES:}

\section{NETHERLANDS}

If the Minister so desires, within six months after the day on which the licensee has proved to have discovered natural gas in an economically producible quantity in a natural gas deposit, the licensee is required to cooperate in:

(a) the establishment, with due observance of the sections 3 and 4, of a limited liability company for the production under the license of natural gas and petroleum from each natural gas deposit, in which the licensee participates for $60 \%$ and the State, or by the Minister appointed limited liability company, all shares of which directly or indirectly are owned by the State, participates for $40 \%$, and

(b) the conclusion of an agreement between the licensee and that limited liability company to be established, by virtue of which the licensee only will produce for account of that limited liability company.... ${ }^{\text {to }}$

If, when granting a production license in pursuance of the circumstances referred to in Article IV, the right referred to in Section 11, second subsection under a., is exercised, such a license furthermore cannot be granted but with the provision that the State or a limited liability company, the shares of which, directly or indirectly, are owned by the State, is appointed as participant in the limited liability company, which is established in conformity with the provision, atțached to that license, ... . ${ }^{41}$

\section{SWEDEN}

The concession may be supplemented by such stipulations as are called upon with a view to the public interest, for example as regards the management of the company concerned,....

The concession may also include conditions referring to the participation of the State in the undertaking, or to the delivery to the State of fees for the concession, calculated in relation to the quantity or the value of the extracted products or otherwise, or a share of the products, or any similar condition. ${ }^{2}$

\section{IRAQ NATIONAL OIL COMPANY (INOC)}

\section{Article 2}

(1) The Company's objectives shall be to engage both inside and outside Iraq in the oil industry in any or all of its phases including exploration and prospecting for oil and natural hydrocarbons; production, transportation, refining, storage and distribution of said substances or of their products or derivatives (petrochemicals) and the manufacture of relevant equipment. The Company shall have the right to trade in all these substances.

(2) The Company for the purpose of achieving its objectives shall have the right to establish companies, singly or jointly with other parties, or participate in existing companies.

(3) The Company shall have the right to enter into contracts, for cooperation in various forms, with companies or organizations engaged in activities related to its objectives, also to purchase or affiliate such companies or organizations.

\section{Provisions Relating to Employment and Training of Nationals}

Another common feature of oil and gas legislation of most oil producing countries is that oil companies are obligated to emplby nationals in their operations. Foreign oil companies are usually specially affected by such obligations. Some provisions set employment targets by prescribing the percentage of the total staff or of skilled or unskilled personnel that must be nationals, provided that suitable numbers of qualified nationals are available (Libya, Egypt, Italy). Other provisions

10 Decree of January 27, 1967 concerning implementation of Article 12 of the Continental Shelf Act, s. 2.

41 Id. Art. VI.

42 Continental Shelf Law, June 3, 1966. 
require simply that the companies must comply with the instructions of the authorities as regards the employment of staff (Denmark). In a few cases, an additional restriction is imposed by laying down the percentage of total salaries and wages to be paid or earned by nationals (Egypt). Quite apart from the provisions of oil and gas legislation and concession contracts which aim at limiting the number of foreign personnel, immigration laws may be applied for the purpose, among others, of restricting the number of foreign personnel in a foreign owned oil company.

The objective of the provisions is two-fold: firstly, to provide job opportunities for nationals and so help to raise local capital, and secondly, participation by nationals in the managerial and technological level of the company, that is, in the so-called "technostructure". The brain of the company is located at this level and it is at the level of technocrats that many important company decisions are made. Participation by nationals at this level of the company's organization provides an opportunity for nationals to influence company decisions, if they choose to do so, in the direction of the national interests of their country.

In addition to offering job opportunities for nationals, oil companies are generally required to give technical training to local employees or offer scholarships locally or abroad for such training (Nigeria, Argentina, Colombia, Venezuela, Libya) and to undertake research locally.

\section{EXAMPLES:}

\section{DENMARK}

The exclusive concession is granted on the following further conditions:

(5) that the concessionaire follows the Minister's direction about employment of native labour in the operation of the concession and as to which of the members of the board of directors and the management must be in possession of Danish citizenship. ${ }^{43}$

\section{$\operatorname{ITALY}$ (Sicily)}

Hiring of Labour

(a) During the permit period the Permittee is required to employ among residents of Sicily not less than $70 \%$ of the total day labour used in the work of exploration.

(b) During the Concession period the Concessionaire is required to employ among Italian residents in Sicily not less than $75 \%$ of the total personnel employed at the beginning of the Concession, and to bring said percentage up to $90 \%$ within 5 years. ${ }^{41}$

\section{PORTUGAL}

The concession holder, taking into account the specialized nature of the works to which this decree refers, will be able to use the foreign specialists who may be necessary without prejudice to the preference which must be given to the employment of suitably qualified Portuguese personnel, the specialization of whom he is entrusted to promote and accelerate with a view to progressive substitution, whenever possible, of the foreign technicians. ${ }^{45}$

\section{NIGERIA}

17(1) In so far as it has not already done so, the Lessee shall at the inception of the operations hereunder start a training scheme for the technical training of suitable Nigerians recruited specially, if necessary, for the purpose. Such scheme shall be

${ }^{43}$ Law No. 181, Exploration and Utilization of Raw Materials in the Underground of the Kingdom of Denmark, May 8, 1950, 8. 3.

"Hydrocarbon Law, Sicily, Art. 17.

is Decree Law for Oil Concessions in the Offshore of Metropolitan Portugal, Art. 47. 
directed towards the training of Nigerians for employment as tradesmen and craftsmen as required by the Lessee in the conduct of its operations hereunder.

(2) The Lessee shall also within a reasonable time commence:

(a) the training of Nigerians in supervisory posts, and

(b) the recruiting and training of professional Nigerian staff for employment in senior managerial grades.

(3) Any such scheme and any such recruitment and training, whether started before or after the inception of the operations hereunder, shall be continuously carried on by the Lessee throughout this Lease and any renewal hereof. ${ }^{46}$

\section{E. PROVISIONS RELATING TO NATIONAL SECURITY AND OTHER OBJECTIVES}

\section{National Security}

National oil or energy policies usually stress the importance of a sufficient, steady and secure supply of oil and gas at reasonable prices to meet the industrial, household and strategic needs of the country. The policies cover both the immediate and foreseeable needs of the country. Of the provisions that give legislative effect to these needs, the commonest include provisions dealing with the preferential supply of oil and gas for national needs before export, creation of national oil companies to engage in all phases of oil and gas operation, creation of national oil and gas reservations, and reduction of the terms of concessions and leases. Only the first class of provisions will be discussed in this paper.

The oil and gas legislation of all oil producing countries have provisions designed to assure sufficient supplies of oil and gas for the internal needs of the countries. The internal needs of the producing country must first be satisfied before producers may export their products. International oil companies usually market large quantities of their products outside the producing countries and as such are more affected than most other oil companies. Under some of the provisions, producers are required to make available, on a pro rata basis, sufficient quantities of their products to meet the national needs of the host country. The requirement may be satisfied by supplying crude oil to local refineries (Libya), or by means of exchange (Algeria), or by supplying finished petroleum products. Under the laws of some countries (Britain, Spain) all production must be delivered to a government monopoly unless authorization is obtained to export the products.

The legislation of most of the countries provides that the government has, in the event of national emergency, the right to requisition or preempt at fair market price the whole or part of the crude or refined products of producers. The government may further require the producers to increase production and if facilities are available, to refine it to such quantity or quality of products as is required for national emergency. In some countries (e.g. Egypt) the right of preemption may be exercised even though there is no national emergency, if a producer stops production or limits it, resulting in a deficiency in national supply.

\section{EXAMPLES:}

\section{ALGERIA}

Article 32. The exploiters of hydrocarbon deposits may be required, on the request of the Minister of Mines, to devote in priority the products of their exploitation 
to the supply of the franc zone, after having satisfied the local consumption needs of the areas of Organization Commune des Regions Sahariennes. This obligation may be fulfilled directly or by means of exchange. ${ }^{47}$

LIBYA

Article 21(2). Should refineries be established in Libya the [Minister of Petroleum Affairs] may require a concession holder to make available at field storage to such refineries, pro rata with other concession holders and at field storage price, sufficient quantities of crude oil from his production in all concessions in Libya to meet the domestic consumption requirements of Libya.... 48

BRITAIN 49

CANADA (Alberta)

The lessee covenants, and it is an express condition upon which this lease is granted, that natural gas produced from the location shall be used within the Province of Alberta, unless the consent of the Lieutenant Governor in Council to its use elsewhere has been previously obtained. Upon any breach of this covenant and condition occurring, whether with or without the consent or knowledge of the lessee, this lease, in 80 far as it relates to natural gas within and under the location, shall forthwith be terminated, shall become null and void, and shall cease to have any further force or effect, and the natural gas within and under the location shall thereupon revert to Her Majesty, freed and discharged from any interest or claim of the lessee or any person or persons whomsoever claiming by, through or under the lessee. 50

\section{Provisions Relating to Other Objectives}

As a general rule, foreign owned companies are permitted, through the issuance of import licenses, to import the equipment they require for their operations in the host country. They must, however, satisfy the authorities that the equipment, craft or vessel cannot be obtained locally; preference must be given to equipment, craft or vessel belonging to or manufactured in the country. Some concession contracts (e.g. Kuwait) provide that tankers flying the flag of the country must be given preference over other tankers in the transportation or export of oil. The main objective of this class of provisions appears to be economic.

There are, of course, other legislative measures that have been employed by some national governments for the purpose of achieving the objectives discussed in this paper. Nationalization of all or part of the stages of petroleum operation as in Mexico, Brazil, and Algeria (marketing) are beyond the scope of this paper because, in principle, nationalization rules out oil and gas operations by foreign enterprise.

Conversely, there are objectives for which no statutory provisions are made, yet such objectives can be inferred from express provisions or from government attitudes and decisions bearing on foreign exploitation of oil and gas resources. Economic nationalism is a case in point. There is the tendency in former colonial countries to identify multinational oil companies with the respective home governments of the companies. Whether for this reason or not, foreign exploitation of oil and gas resources generate social, political and economic pressures. Rightly or wrongly, the clamour in the host country is sometimes motivated simply by the desire to manage the resources of the country unhindered by foreign interference. Within recent years, the same or similar clamour has been partly responsible for changes in oil and

\footnotetext{
17 Statute No. 58-III, November 22, 1958.

48 The Petroleum Law, 1955, Art. 21(2).

49 See supra, n. 35.

so Clause 6 of the Petroleum and Natural Gas Lease of the Government of the Province of Alberta, Canada.
} 
gas legislation of a number of oil producing countries in the Middle East, North Africa and South America. Joint venture arrangements, service contracts and state monopolies of one or more phases of the oil industry are attributable to nationalistic pressures.

\section{F. CONCLUSION}

This paper is not a comprehensive study of the controversial subject of "foreign ownership" in the oil and gas industry. It does not attempt to present the pros and cons of the subject and it draws no conclusions. There is much evidence in support of the view that, in the long run, foreign exploitation of oil and gas under the leasing system ${ }^{51}$ gives to the government and peoples of an oil producing country more economic and social benefits than foreign exploitation under the concession system together with profit-sharing and joint venture arrangements. ${ }^{52}$ However, this paper does not examine this aspect of "foreign ownership". It is simply a comparative study of the provisions of oil and gas legislation affecting foreign exploitation of these resources in various oil and gas producing countries.

To recapitulate, certain trends are evident from legislation and concession contracts studied, namely:

1. The legislation of each of the producing countries mentioned in this paper asserts jurisdiction and control over oil and gas in place. 2. In varying degrees, the legislation of each of the countries is designed to encourage foreign capital. In many countries where the industry has been nationalized, foreign oil men now operate under service contracts.

3. Although the legislation encourages foreign capital, especially by means of numerous tax and other incentives, it is also designed to ensure that foreign exploitation gives preference to national interests of the host country over those of the home countries of foreign oil companies. In particular, certain provisions are designed to serve one or more of the following purposes:

(a) to provide government revenue and local capital from foreign exploitation;

(b) to ensure effective control by government over oil company ownership, management and decisions;

(c) to supply energy needs of the country in preference to exports of oil and gas; and

(d) to provide job opportunities and managerial and technical skills as well as training for nationals.

Corresponding provisions vary in substance and in detail from one oil producing country to another, depending on each country's political, social and economic aspirations.

Reserved for special mention is government regulation of the price of oil and gas. Oil and gas legislation of each of the countries makes provisions for it. However, oilmen should take heart: for nine centuries governments have been relentlessly regulating the prices of several important commodities:

These women [the brewers of the medieval period] had to contend with the multifarious medieval laws governing quality, quantity and price legislation indicating clearly the importance of beer in everyday life. The role of bread and beer in the

\footnotetext{
31 As it operates in Alberta, Canada and other jurisdictions in North America.

${ }^{32}$ As it operates in the countries of North Africa, Middle East and in some European countries.
} 
English diet is evident from the price regulations which had been imposed on these commodities by the thirteenth century. There was an "Assize of Bread and Ale", a special court, probably as early as the Norman Conquest, to set fair prices for these two basic commodities. ${ }^{53}$

\section{APPENDIX \\ RESOLUTION NO. 1803}

Adopted by the United Nations General Assembly on 14 December 1962 concerning Permanent Sovereignty over Natural Resources:

"The General Assembly,

"Recalling its resolution 523 (VI) of 12 January 1952 and 626 (VII) of 21 December 1962

"Bearing in mind its resolution 1314 (XII) of 12 December 1958, by which it established the Commission on Permanent Sovereignty over Natural Resources and instructed it to conduct a full survey of the status of permanent sovereignty over natural wealth and resources as a basic constituent of the right to self-determination, with recommendations, where necessary, for its strengthening, and decided further that, in the conduct of the full survey of the status of the permanent sovereignty of peoples and nations over their natural wealth and resources, due regard should be paid to the rights and duties of States under international law and to the importance of encouraging international cooperation in the economic development of developing countries,

"Bearing in mind resolution 1515 (XV) of 15 December, 1960, in which it recommended that the sovereign right of every State to dispose of its wealth and its natural resources should be respected,

"Considering that any measure in this respect must be based on recognition of the inalienable right of all States freely to dispose of their natural wealth and resources in accordance with their national interests, and on respect for the economic independence of States,

"Considering that nothing in operative paragraph 4 of the present resolution in any way prejudices the position of any Member State on any aspect of the question of the rights and obligations of successor States and Governments in respect of property acquired before the accession to complete sovereignty of countries formerly under colonial rule, "Noting that the subject of succession of States and Governments is being examined as a matter of priority by the International Law Commission,

"Considering that it is desirable to promote international cooperation for the economic development of developing countries and that economic and financial agreements between the developed and the developing countries must be based on the principles of equality and of the right of peoples and nations to self-determination,

"Considering that the provision of economic and technical assistance, loans and increased foreign investment must not be subject to conditions which conflict with the interests of the recipient State,

"Considering the benefits to be derived from exchanges of technical and scientific information likely to promote the development and use of such resources and wealth, and the important part which the United Nations and other international organizations are called upon to play in that connection,

"Attaching particular importance to the question of promoting the economic development of developing countries and securing their economic independence,

"Noting that the creation and strengthening of the inalienable sovereignty of states over their natural wealth and resources reinforces their economic independence,

"Desiring that there should be further consideration by the United Nations of the subject of permanent sovereignty over natural resources in the spirit of international cooperation in the field of economic development, particularly that of the developing countries,

"Declares that:

" 1 . The right of peoples and nations to permanent sovereignty over their natural wealth and resources must be exercised in the interest of their national development and of the well-being of the people of the State concerned; 
"2. The exploration, development and disposition of such resources, as well as the import of the foreign capital required for these purposes, should be in conformity with the rules and conditions which the peoples and nations freely consider to be necessary or desirable with regard to the authorization, restriction or prohibition of such activities; "3. In cases where authorization is granted, the capital imported and the earnings on that capital shall be governed by the terms thereof, by the national legislation in force, and by international law. The profits derived must be shared in the proportions freely agreed upon, in each case, between the investors and the recipient State, due care being taken to ensure that there is no impairment, for any reason, of the State's sovereignty over its natural wealth and resources;

"4. Nationalization, expropriation or requisitioning shall be based on grounds or reasons of public utility, security or the national interests which are recognized as overriding purely individual or private interests, both domestic and foreign. In such cases the owner shall be paid appropriate compensation, in accordance with the rules in force in the State taking such measures in the exercise of its sovereignty and in accordance with international law. In any case, where the question of compensation gives rise to a controversy, national jurisdiction of the State taking such measures shall be exhausted. However, upon agreement by sovereign States and other parties concerned, settlement of the dispute should be made through arbitration of international adjudication;

"5. The free and beneficial exercise of the sovereignty of peoples and nations over their natural resources must be furthered by the mutual respect of States based on their sovereign equality;

" 6 . International cooperation for the economic development of developing countries, whether in the form of public or private capital investments, exchange of goods and services, technical assistance, or exchanges of scientific information, shall be such as to further their independent national development and be based upon respect for their sovereignty over their natural wealth and resources;

"7. Violation of the rights of peoples and nations to sovereignty over their natural wealth and resources is contrary to the spirit and principles of the United Nations Charter and hinders the development of International cooperation and the maintenance of peace; "8. Foreign investment agreements freely entered into by or between sovereign States shall be observed in good faith; States and international organizations shall strictly and conscientiously respect the sovereignty of peoples and nations over their natural wealth and resources in accordance with the United Nations Charter and the principles set forth in this resolution;

\section{II}

"Welcomes the decision of the International Law Commission to speed up its work on the codification of the topic of responsibility of States for the consideration of the General Assembly;

\section{III}

"Requests the Secretary-General to continue the study of the various aspects of permanent sovereignty over natural resources, taking into account the desire of Member States to ensure the protection of their sovereign rights while encouraging international cooperation in the field of economic development, and to report to the Economic and Social Council and to the General Assembly if possible at its eighteenth session. 